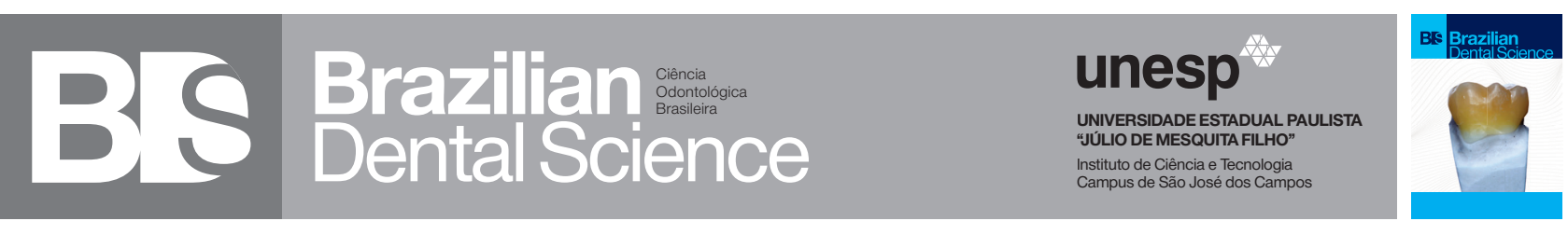

\title{
Acting and knowledge of emergency rescue teams in dental trauma
}

Atuação e conhecimento de equipes de resgate de emergência em casos de trauma dental

Amjad ABU HASNA ${ }^{1}$, Carlos Henrique FERRARI ${ }^{1}$, Tatiane Sampaio BITTENCOURT ${ }^{1}$, Carlos Henrique Ribeiro CAMARGO ${ }^{1}$, Cláudio Antonio Talge CARVALHO ${ }^{1}$

1 - São Paulo State University (Unesp), Institute of Science and Technology, São José dos Campos - Department of Restorative Dentistry Endodontic Division - São José dos Campos - SP - Brazil.

\begin{abstract}
Objective: Dental trauma is regularly frequent in patients assisted by rescue teams at sites of accidents and by emergency teams in hospitals. However, these professionals are given little or no information about taking care of the injured teeth and mouth. The aim of this study was to evaluate the level of knowledge of rescue and emergency teams' professionals (physicians, Nurses, and Paramedics) concerning dental trauma first management. Material and methods: 196 professionals of rescue and emergency units had received a standard questionnaire of 5 questions concerning dental trauma first management and reserving avulsed dental tissue (a tooth or its fragment). Results: The results showed high level of attendance of dental trauma patients by paramedics, nurses, and physicians, with very low-level knowledge about dealing with such cases, and with moderate results about the best medium to preserve the avulsed tooth, and the actions taken during the rescue process. Conclusion: Our results show a high occurrence of cases of dental trauma attended by rescue and emergency medical teams, with a lack of knowledge, this suggests a need for more educational campaigns for these professionals with a long-term follow-up.
\end{abstract}

\section{KEYWORDS}

Traumatic dental injury; Tooth Avulsion; Emergency rescue teams.

\section{RESUMO}

Objetivo: O traumatismo dentário é regularmente freqüente em pacientes atendidos por equipes de resgate em locais de acidentes e por equipes de emergência em hospitais. No entanto, esses profissionais recebem pouca ou nenhuma informação sobre como cuidar e atuar em casos de lesões traumáticas em tecidos duros e moles. O objetivo deste estudo foi avaliar o nível de conhecimento dos profissionais das equipes de resgate e emergência (médicos, enfermeiros e paramédicos) sobre o atendimento do traumatismo dentário. Material e métodos: 196 profissionais das unidades de resgate e emergência receberam um questionário padronizado de 5 questões referentes ao atendimento do traumatismo dentário e preservação de tecido dentário avulsionado (um dente ou seu fragmento). Resultados: os resultados mostraram um alto nível de atendimento de pacientes de traumatismo dentário por paramédicos, enfermeiros e médicos, com conhecimento muito baixo sobre como lidar com esses casos, e com resultados moderados sobre o melhor meio para preservar o dente avulsionado, e as ações tomadas durante o processo de resgate. Conclusão: há uma alta ocorrência de casos de traumatismos dentários atendidos por equipes de resgate e emergência, com falta de conhecimento, o que sugere a necessidade de mais campanhas educativas para esses profissionais com acompanhamento a longo prazo.

\section{PALAVRAS-CHAVE}

Trauma dentaria; Avulsão dentária; Equipes de resgate de emergência. 


\section{INTRODUCTION}

$\mathrm{T}$ raumatic dental injury (TDI) is a public dental health problem due to its frequency, occurrence at a young age, costs and that treatment may continue for the rest of the patient's life [1]. TDI in children and adolescents has been extensively studied over the last few decades, with recent studies reporting prevalence rates ranging from $6 \%$ to $25 \%$ in different populations of different places around the world [2-6]. In Brazil, a recent study showed that TDI was found in $31.7 \%$ of the examined children affecting a total of 214 teeth [7]. TDI sometimes causes damage, requiring complex and onerous repairs [8].

In Brazil, the emergency service units are appropriate places to handle patients care during acute specific conditions, where there are expert working teams, which can be divided into 3 categories [9], emergencies room; first aid unites; and hospitals according to the ministry of health [10].

As well as, the rescue teams, which is divided into 2 categories [10], the prehospital care (In Portuguese APH): consists of 2 professional teams, the first one called originating health professionals which included physician, nurse and nursing technicians. The second group is called non-originating health professionals which provided by policemen (federal, civil, military and municipal guards), firemen and emergency vehicle drivers. In addition to the pre-hospital rescue (In Portuguese SPH): A team moves to relief situations with greater complexity in different areas. In 1985, the Brazilian Society of Trauma Nurses (SOBET) was created, being the first association of specialized nurses in trauma [9].

However, physicians, nurses, and rescue teams are not dentists. Unfortunately, according to the data above, there are no dentists involved in the rescue teams or emergency units, and according to various studies [11-13] these professionals generally receive little or no training related to the
TDI first management, and thus, have poor knowledge of the basic procedures involved. Dentists do not firstly assist more severe cases with greater damage, but instead they are assisted by field rescue teams, consisting of physicians, and paramedics, or emergency teams of nurses and physicians at hospitals. Therefore, the action of these professionals is seriously important to minimize future dental treatment complications, resulting in a better prognosis of these cases and decreasing the costs and complications of future restoration works $[12,14]$.

This study aimed to evaluate the level of knowledge of rescue and emergency teams' professionals (Physicians, Nurses, and Paramedics) concerning the dental trauma; and the best ways to preserve the dental tissue and avulsed teeth during accidents.

\section{MATERIAL AND METHODS}

A total of 196 professionals involved in emergency care and first-aid unites as well as rescue teams of trauma patients were selected for this study. Members of two rescue teams and two hospitals of the same region (São José dos Campos, Brazil) were distributed as the following: 79 paramedics, 63 nurses, and 54 physicians, where all of them received a standardized questionnaire focusing on their actions in cases of TDI management (Table 1).

Table 1 - Standardized questionnaire about professional actions concerning dental trauma management

\begin{tabular}{|c|c|c|c|c|}
\hline \multicolumn{5}{|c|}{$\begin{array}{l}\text { Question. } 1 \text { Have you ever received any training about TDI man- } \\
\text { agement }\end{array}$} \\
\hline \multicolumn{3}{|c|}{ Yes } & \multicolumn{2}{|l|}{ No } \\
\hline \multicolumn{5}{|c|}{ Question. 2 Have you ever dealt with TDI case during your carrier } \\
\hline \multicolumn{3}{|c|}{ Yes } & \multicolumn{2}{|l|}{ No } \\
\hline \multicolumn{5}{|c|}{$\begin{array}{l}\text { Question. } 3 \text { What would you do if you found a tooth or tooth frag- } \\
\text { ment during the attendance }\end{array}$} \\
\hline Discard it & $\begin{array}{l}\text { Give it } \\
\text { to the } \\
\text { family }\end{array}$ & $\begin{array}{c}\text { Place it } \\
\text { inaliquid } \\
\text { medium }\end{array}$ & $\begin{array}{l}\text { Place it in the mouth } \\
\text { in its original position }\end{array}$ & $\begin{array}{l}\text { Idon't } \\
\text { know }\end{array}$ \\
\hline \multicolumn{5}{|c|}{ Question.4 What is the best method to store an avulsed tooth } \\
\hline $\begin{array}{l}\text { Dry } \\
\text { medium }\end{array}$ & $\begin{array}{l}\text { Patient } \\
\text { mouth }\end{array}$ & Water & $\begin{array}{l}\text { Saline } \\
\text { solution }\end{array}$ & $\begin{array}{l}\text { Idon't } \\
\text { know }\end{array}$ \\
\hline
\end{tabular}


The following questions were evaluated: whether they had received any orientation or training on TDI management; whether or not they had dealt with any case of TDI during their career; whether or not they could correctly choose one of four alternatives concerning the appropriate action if they found a tooth or tooth fragment; and whether or not they could correctly choose from the six options the best method to store an avulsed tooth. The professionals questioned by a team of dental students. The interviewers were not identified by name.

The data were then collected and analyzed through \%multprop macro. This macro performs multiple comparisons tests on proportion data using Tukey's honest significant difference test with $\mathrm{P} \leq 0.05$. This macro requires two input columns, where the first column contains the number of successes (the right answers), and the second column contains only integer data.

In questions 1 and 2, the answers "YES" were considered as success or right answers. In question 3, the answers (Place it in a liquid medium, or Place it in the mouth in its original position) were considered as right answers. In question 4, the answers (Patient mouth, milk, and saline solution) were considered as right answers. The data were analyzed by Minitab (Minitab® 17.1.0, by Microsoft, USA).

\section{RESULTS}

In question 1 there was no difference, in terms of that around $7.5 \%$ of the questioned professionals had received a training about TDI management. (Figure 1)

In question 2 there was a significant difference between physicians group and paramedics group but not to nurses group. About $96.29 \%$ of physicians had dealt with TDI case during their carrier, $84.12 \%$, and $77.21 \%$ of nurses and paramedics respectively. (Figure 2)

In question 3 there was no difference among the 3 groups, in which $49.36 \%, 38.09 \%$, and $57.40 \%$ of paramedics, nurses, and physicians respectively responded right answers. (Figure 3)
In question 4 there was no difference among the 3 groups, in which $68.36 \%, 53.96 \%$, and $72.22 \%$ of paramedics, nurses, and physicians respectively responded right answers. (Figure 4)

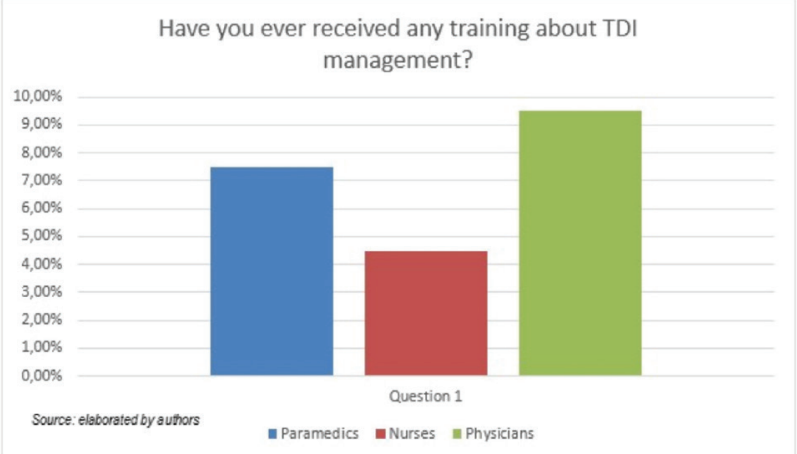

Figure 1- Statistical difference about the answers of question 1.

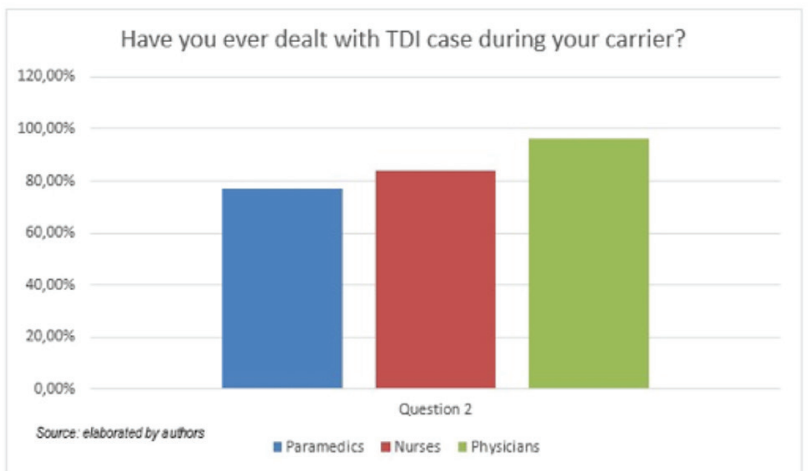

Figure 2 - Statistical difference about the answers of question 2.

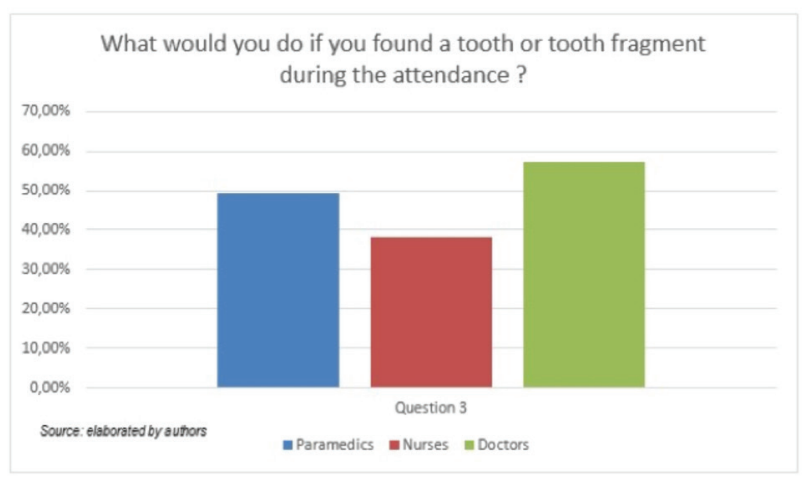

Figure 3 - Statistical difference about the answers of question 3. 


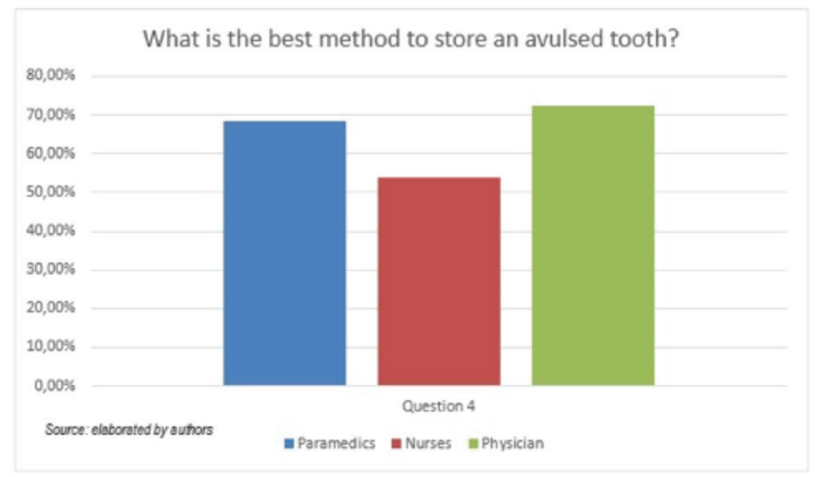

Figure 4 - Statistical difference about the answers of question 4.

\section{DISCUSSION}

The occurrence of TDI had been studied by a lot of researchers all over the world; a high prevalence of TDI has been reported in many countries. However, most studies of TDI have reported its prevalence in permanent teeth [15-18].

TDI is firstly treated by the parents, family, teachers, or professionals in sport or physical education [19-21]. However, in more severe cases, the care is provided by external rescue teams, consisting of paramedics and physicians, at the moment of accidents followed by emergency teams, nurses and physicians at hospitals [10].

Piovesan et al. [7], in their study, evaluated the level of dental trauma among the children of one school, 8 examiners and 24 assistants participated in the study, had received training and calibration exercises to assess reproducibility before the survey by one benchmark examiner. Training involved a theoretical explanation, and a discussion using clinical photographs of 30 exfoliated primary teeth, which reveals the low level of knowledge concerning the dental trauma care which agrees with our results.

According to Frujeri and Costa [22] a study concerning the effect of a single dental health education on the management of permanent avulsed teeth by different groups of professionals, showed statistically significant change in the performance of professional groups after information was provided $(\mathrm{P}<$ 0.0001), through a lecture, which reveals that the education is extremely important to favor the knowledge on prevention and emergency management of an avulsed tooth [22].

In a recent study, Cully et al. [23], concluded that only $19 \%$ of the physicians in this study of the American community, including 285 physicians, were confident about treating TDI, where another study suggested similar results revealed that ER physicians has no knowledge about avulsed teeth management, in a crosssectional survey focused on 150 ER physicians, in a study focused on the Saudi community [24]. Even more, another study questioned 282 dentists, revealed that the majority of them have inadequate knowledge about avulsed teeth management, in a study directed to the Pakistani community [25].

However, Aren et al. [26], revealed that ER physicians have a good knowledge about avulsed teeth and fractured crowns management, but they have a poor knowledge about luxation management, in this study which was directed to the Turkish community [26].

There is little knowledge available, both in emergency care manuals for the public and in guides for nurses and physicians, which is the possible reason for widespread ignorance [27]. However, Baginska and Wilczynska-Borawska [28] showed that nurses' knowledge about tooth avulsion was at an appropriate level, and one statistically significant correlation between the level of knowledge and previous dental trauma management training was revealed ( $\mathrm{P}$ $<0.01)$. In another study, Loken, Wang, Wigen [29], reported that majority of health nurses have knowledge about TDI management [28].

It is a fact that a significant increase in knowledge after prior training [7,22,29] which verify the need for more educations directed for the workers in the health care area [22], which show promising results and significant improvement in the knowledge of the professionals [30].

Concerning this aspect, our study demonstrates that despite a high occurrence of cases of dental trauma seen by the professionals, 
few professionals had received training or information about dealing with, and this observation was true across all the studied groups.

The results of our study also reveal, in line with other similar works, low level knowledge both in the conduct of trauma cases and in relation to the storage media of avulsed teeth [11-14].There are also few differences regarding the level of this knowledge among different groups of professionals [12-14,22].

The low levels of knowledge found among health professionals, together with results obtained in other studies evaluating other groups involved in the urgent care of dental trauma, suggest that many cases could be better attended if orientation campaigns were developed in schools and hospitals.

\section{CONCLUSION}

- Our results show a high occurrence of cases of dental trauma attended by rescue and emergency medical teams, with a lack of knowledge on the subject. This suggests a need for more educational campaigns for these professionals with a long-term follow-up;

- It should be recommended for medical schools to pay more attention on TDI first management;

- More and wider studies should be realized to investigate the best methods in TDI first management.

\section{ACKNOWLEDGMENTS}

The authors deny any conflicts of interest.

\section{REFERENCES}

1. Glendor U. Epidemiology of traumatic dental injuries--a 12 year review of the literature. Dent Traumatol.2008Dec;24(6):603-11.

2. Navabazam A, Farahani SS. Prevalence of traumatic injuries to maxillary permanent teeth in 9- to 14-year-old school children in Yazd, Iran. Dent Traumatol.2010 Apr;26(2):154-7.

3. David J,Astrøm AN, Wang NJ. Factors associated with traumatic dental injuries among 12-year-old schoolchildren in South India. Dent Traumatol. 2009 0ct;25(5):500-5.
4. Altun C, Ozen B, EsenlikE, Guven G, Gürbüz T, Acikel C, etal. Traumatic injuries to permanent teeth in Turkish children, Ankara. Dent Traumatol.2009 Jun;25(3):309-13.

5. Naidoo S, Sheiham A, Tsakos G. Traumatic dental injuries of permanent incisors in 11- to 13-year-old South African schoolchildren. Dent Traumatol. 2009 Apr;25(2):224-8.

6. Locker $D$. Prevalence of traumatic dental injury in grade 8 children in six Ontario communities. Can J Public Health. 2005 Feb;96(1):73-6.

7. Piovesan C, Guedes RS, Casagrande L, Ardenghi TM. Socioeconomic and clinical factors associated with traumatic dental injuries in Brazilian preschool children. Braz Oral Res. 20120ct;26(5):464-70.

8. Wong FSL, Kolokotsa K. The cost of treating children and adolescents with injuries to their permanent incisors at a dental hospital in the United Kingdom. Dent Traumatol. 2004 Dec;20(6):327-33.

9. Gomes AL. Emergência: planejamento e organização da unidade. Assistência de enfermagem. São Paulo: Pedagógica e Universitária; 1994.

10. Ministry of Health (BR). Basic terminology in health. 2nd ed. Brasilia: Ministry of Health Documentation Centre; 1985.

11. SubhashrajK. Awareness of management of dental trauma among medical professionals in Pondicherry, India. Dent Traumatol. 2009 Feb;25(1):92-94.

12. Díaz J,Bustos L, HerreraS, Sepulveda J. Knowledge of the management of paediatric dental traumas by non-dental professionals in emergency rooms in South Araucanía, Temuco, Chile. Dent Traumatol. 2009 Dec;25(6):611-9.

13. Lin S, Levin L, Emodi 0, Fuss Z, Peled M. Physician and emergency medical technicians' knowledge and experience regarding dental trauma. Dent Traumatol. 2006 Jun;22(3):124-1.

14. Walker A, Brenchley J.It's a knockout: survey of the management of avulsed teeth. Accid Emerg Nurs. 2000 Apr;8(2):66-70.

15. Do Espirito Santo Jácomo DR, Campos V.Prevalence of sequelae in the permanent anterior teeth after trauma in their predecessors: alongitudinal study of 8 years. Dent Traumatol. 2009 Jun;25(3):300-4.

16. Cavalcanti AL, Bezerra PKM, de Alencar CRB, Moura C. Traumatic anterior dental injuries in 7- to 12-year-old Brazilian children. Dent Traumatol. 2009 Apr;25(2):198-202.

17. Fakhruddin KS, Lawrence HP, Kenny DJ, Locker D. Etiology and environment of dental injuries in 12- to 14-year-old Ontario schoolchildren. Dent Traumatol. 2008 Jun;24(3):305-8.

18. Soriano EP,Caldas A de F, Diniz De Carvalho MV, Amorim Filho HDA. Prevalence and risk factors related to traumatic dental injuries in Brazilian schoolchildren. Dent Traumatol. 2007 Aug;23(4):232-40.

19. Chan AW, Wong TK, Cheung GS. Lay knowledge of physical education teachers about the emergency management of dental trauma in Hong Kong. Dent Traumatol. 2001Apr;17(2):77-85.

20. Arikan V, SönmezH. Knowledge level of primary school teachers regarding traumatic dental injuries and their emergency management before and after receiving an informative leaflet. Dent Traumatol. 2012 Apr;28(2):101-7.

21. Marcano-Caldera M, Mejia-Cardona JL, Parra Sanchez JH, Méndez de laEspriellaC, Covo MoralesE, Sierra Varón G, etal. Knowledge about emergency dental trauma management among school teachers in Colombia: A baseline study to develop an education strategy. Dent Traumatol. 2018 Jun;34(3):164-74.

22. Frujeri M de LV, CostaED. Effect of a single dental health education on the management of permanent avulsed teeth by different groups of professionals. Dent Traumatol. 2009 Jun;25(3):262-71. 
23. Cully M, Cully J, NietertPJ, Titus MO. Physician Confidence in Dental Trauma Treatment and the Introduction of a Dental Trauma Decision-Making Pathway for the Pediatric Emergency Department. Pediatr Emerg Care. 2018 Apr 24;

24. Bahammam LA. Knowledge and attitude of emergency physician about the emergency management of tooth avulsion. BMC Oral Health. $2018 \mathrm{Apr}$ 2:18(1):57.

25. Zafar K, Ghafoor R, Khan FR, Hameed MH. Awareness of dentists regarding immediate management of dental avulsion: Knowledge, Attitude, and Practice study. JPak Med Assoc. 2018 Apr;68(4):595-9.

26. Aren A, Erdem AP,Aren G, Şahin ZD, Güney Tolgay C, Çayırcı M, et al Importance of knowledge of the management of traumatic dental injuries in emergency departments. Ulus Travma Acil Cerrahi Derg. 2018 Mar:24(2):136-14.
27. Zadik Y.Oral trauma and dental emergency management recommendations of first-aid textbooks and manuals. Dent Traumatol. 2007 0ct;23(5):304306.

28. Løken SY, Wang NJ, Wigen TI. Health nurses' experiences and attitudes regarding collaboration with dental personnel. BMC Oral Health. 2016 Jun 6;16(1):66.

29. Baginska J, Wilczynska-Borawska M. Knowledge of nurses working at schools in Bialystok, Poland, of tooth avulsion and its management. Dent Traumatol. 2012 Aug;28(4):314-19.

30. Al Sari S,Kowash M, Hussein I,Al-Halabi M. An educational initiative for dubai school nurses and physical education teachers on the management of traumatic dental injuries. J Sch Nurs. 2018 Jan 1;1059840518780306.

\section{Amjad Abu-Hasna}

(Corresponding address)

Department of Restorative Dentistry, Endodontics, São Paulo State University (UNESP), Institution of science and technology. São José dos Campos, São Paulo, Brazil.

Av. Francisco José Longo, 777 Bairro São Dimas, São José dos Campos, São

Paulo - Brazil. 12245-000

E-mail: d.d.s.amjad@gmail.com

Date submitted: 2019 Jan 14

Accept submission: 2019 May 09 